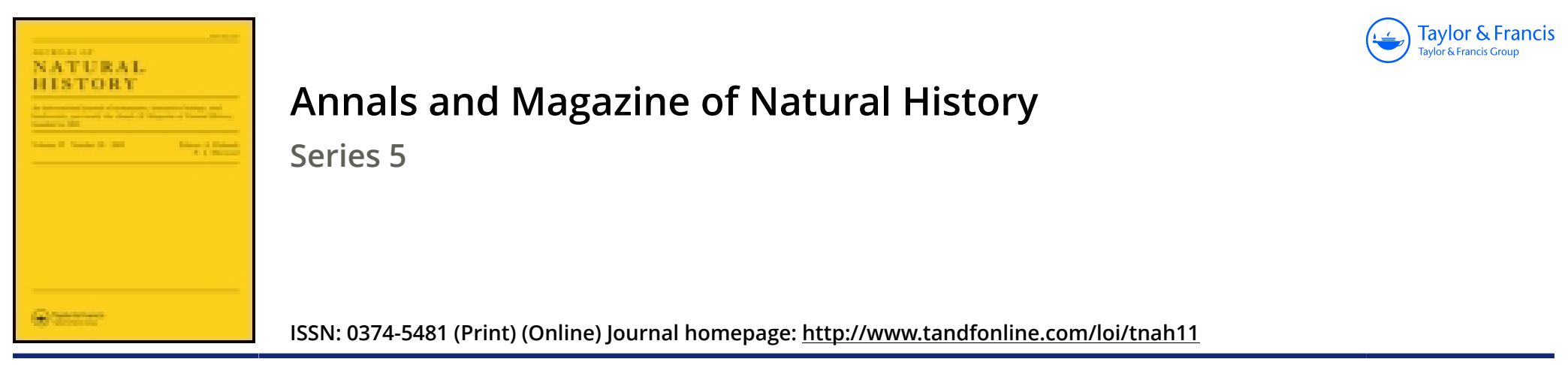

\title{
On the histolysis of the muscles of the larva during the postembryonic development of the diptera
}

\section{M.H. Viallanes}

To cite this article: M.H. Viallanes (1881) On the histolysis of the muscles of the larva during the postembryonic development of the diptera, Annals and Magazine of Natural History, 7:40, 352-354, DOI: $10.1080 / 00222938109459528$

To link to this article: http://dx.doi.org/10.1080/00222938109459528

\section{Published online: 07 Oct 2009.}

\section{Submit your article to this journal $\square$}

Џ Article views: 3 
tub, having a capacity of about 75 gallons, which it filled. This tub was known to hold $700 \mathrm{lbs}$. of codfish. The gravity of the Architeuthis is probably about the same as that of the fish. This would indicate more nearly the actual weight of one of these creatures than any of the mere estimates that have been made, which are usually much too great. Allowing for the parts of the arms that had been destroyed, this specimen would, perhaps, have weighed nearly 1000 lbs.

Among the numerous other vessels that were fortunate in securing this kind of bait, Capt. Collins mentioned the following:The schr. 'Sarah P. Ayer,' Capt. Oakly, took one or two. The 'E. R. Nickerson,' Capt. M'Donald, secured one that had its arms and was not entirely dead; so that it was harpooned. Its tentacular arms were 36 feet long. The schr. 'Tragabigzanda,' Capt. Mallory, secured three in one afternoon. These were from 8 to 12 feet long, not including the arms. These statements are confirmed by other fishermen, some of whom state that the " big squids" were also common, during the same season, at the "Flemish Cap," a bank situated some distance north-east from the Grand Banks.

The cause of so great a mortality among these great Cephalopods can only be conjectured. It may have been due to some disease epidemic among them, or to an unusual prevalence of deadly parasites or other enemies. It is worth while, however, to recall the fact that these were observed at about the same time, in autumn, when most of the specimens have been found cast ashore at Newfoundland, in different years. This season may, perhaps, be just subsequent to their season for reproduction, when they would be so much weakened as to be more easily overpowered by parasites, disease, or other unfavourable conditions.-Amer. Journ. Sci., March 1881 .

On the Histolysis of the Muscles of the Larva during the Postembryonic Development of the Diptera. By M. H. Vialcanes.

It has long been known that all the muscles of the larva of the fly disappear at the moment when the insect passes into the pupa state; but no observer seems to me to have studied the phenomena which accompany this disappearance, known under the name of histolysis. In my investigations upon this subject I have examined more than 400 sections* made across entire larvæ and pupæ of Musca vomitoria, previously fixed by picric acid, hardened by alcohol, and coloured with carmine. To arrive at a correct understanding of the phenomena which characterize the histolysis of muscle, it is desirable, in the first place, to determine exactly the structure of the primitive bundle in the larva. Before the latter has become motionless the primitive bundle, observed in a transverse section, presents a sarcolemma enclosing the contractile mass, which exhibits the characteristic pattern of Cohnheim's aroas, and, further, nuclei. Of these, some are situated beneath the sarcolemma, the others in the heart of the contractile mass; it is difficult

* All these sections are preserved. 
to distinguish a double contour in them ; they are lentioular, pretty strongly coloured red by carmine, and present in their interior some darker granules. From the first day of pupal life the primitive bundles thus constituted begin to disappear, and this according to two different modes, both of which may be observed in the same animal. One of these modes is characterized by the excessive activity and proliferation of the muscular nuclei ; the other, on the contrary, by their degenerescence and death.

1. Disappearance of the Muscle accompanied by Proliferation of the Nuclei.-In the bundles which disappear in accordance with this mode, the sarcolemma has disappeared even before the envelope of the pupa has acquired its characteristic brown appearance ; the contractile substance has become homogeneous; the nuclei, both those situated beneath the sarcolemma and those in the midst of the contractile mass, have become spherical, and acquired the property of being coloured by carmine of a very dark purplish red, which characterizes them. Snch a nucleus soon acquires the value of a complete cell; it is surrounded by a layer of protoplasm, which is itself clothed with an enveloping membrane. In this protoplasm are seen four or five spherical granules of a bright rose-colour; these granules enlarge, and soon attain the size of the nucleus, when there is produced a mulberry-like mass composed of five or six grains lodged in a common envelope. One of these grains, the true muscular nucleus, is of a purple-red, while the others are bright rose-colour. The membrane soon disappears, and the purple and rose-coloured nuclei separate.

This proliferation of the muscular nucleus takes place on the spot; and the contractile substance becomes absorbed around it to lodge these new formations. These light rose-coloured nuclei, the mode of formation of which we have just seen, multiply in their turn by a mode analogous to that which gave them birth. In proportion as the embryonic cells thus produced increase in number the contractile substance is absorbed. In a section the primitive bundle then appears constituted as follows:-The contractile substance, which has become perfectly homogeneous, exhibits a deeply notched sinuous border; these sinuosities are occupied by the embryonic cells, due to the proliferation of the muscular nuclei ; and they are deeper in proportion as this accumulation of embryonic cells is more considerable. The contral part of the contractile mass appears pierced with holes of irregular outline, filled with embryonic cells due to the proliferation of the intramuscular nuclei.

At a more advanced stage the place that was occupied by the muscular bundle is indicated only by a mass of embryonic cells in course of incessant proliferation.

2. Disappearance of the Muscle accompanied by the Degenerescence and Death of its Nuclei.-After the disappearance of the sarcolemma the muscular nuclei appear with a very distinct envelope presenting a double contour; they still retain their lenticular form; their centre is occupied by a small spherule formed of fine granules, which are then the only coloured parts of the nucleus. The granules Ann. \& Mag. N. Hist. Ser. 5. Vol. vii. 
which constitate this spherule become fewer and fewer; they seem to separate from each other; and finally they disappear; the nucleus is then represented only by its envelope, which looks like an empty shell. While the nucleus is undergoing these transformations the contractile substance gradually disappears, melting away, so to speak, and this in so regular a manner that the general form of the bundle is not altered. The product of this sort of dissolution seems to be a colourless very finely granular substance, enveloping the portion of the contractile mass that has not yet disappeared. In this granular mass we find the muscular nuclei in their place and in all the degrees of degeneration that I have just indicated.

Thus the museles of the larva are destroyed at the moment when the latter passes to the pupa state, and this in two quite different modes. In the first case the muscular nuclei, becoming actire, proliferate and give origin to a whole swarm of embryonic cells; and these grow and multiply at the expense of the contractile mass, which seems to disappear before their invasion. In the second case the muscular nuclei seem to degenerate and die, while the contractile substance gradually disappears as by a regular solution.Comptes Rendus, February 21, 1881, p. 416.

\section{On a new Form of Segmental Organ in the Trematodes.} By M. E. Mack.

The authors who have observed the ciliated organs in connexion with the rasculo-excretory apparatus of the Trematodes (Thiry, Bütschli, $\delta$. Fraipont) have described them in the species that they have studied as little ciliated funnels, often unicellular, each bearing upon a differentiated plate a vibratile flagellum. In studying a small Distomum from the intestine of Vespertilio murinus we have ascertained the existence of a very distinct conformation.

The ciliated organ is single. It is a pretty large cup situated in the median line towards the posterior third of the body, immediately beneath the transverse vitelloduct. Its diameter is nearly half that of the ventral disk, which is situated a little above it. Its orifice, turned towards the ventral surface of the body, is clothed with a row of long vibratile cilia, which, when they are in movement, give it the aspect of one of the ciliated wheels of certain Rotifera. From this ciliated funnel start four vessels. The two superior are directed upwards, and soon elude observation. The two inferior have a transverse direction; after a short course they open each into the corresponding branch of the great terminal cavity of this apparatus.

This Distomum has great analogy with $D$. ascidia of Van Beneden. It differs from it, however, in the place occupied by the vitellogenes. Instead of being in the anterior part of the body, in front of the second disk, they occupy its posterior part. They are two ramified glands in the form of an $H$, situated below the ovary, against the upper extremity of the two large branches of the excretory vesicle; the transverse vitelloduct passes immediately above the ciliated organ in question, and presents a pyriform dilatation in its median part. The intestine is formed by two wide cæca, which 